\title{
Aleš Čakalić
}

\section{Ideologija v novejšem srbskem in hrvaškem filmu}

\section{Uvod}

Filmske študije so v zadnjih dveh desetletjih izdatno reflektirale politična in ideološka sporočila filmov, ki so na območju razpadajoče in nato razpadle Jugoslavije nastali po letu 1991. V začetku je teoretska refleksija filme iz te geopolitične regije še uvrščala pod krovni pojem vzhodnoevropskega filma, nato je Dina Iordanova (2001) uvedla izraz balkanski film, v debato o balkanskem filmu pa je posegel tudi Fredric Jameson (2004). Leta 2007 Pavle Levi v razpravo uvede pojem postjugoslovanskega filma, ki se odtlej močno uveljavi; tako je do danes v svetu na temo postjugoslovanskega filma izšlo že okrog 10 znanstvenih monografij in še nekaj desetkrat več znanstvenih člankov. Zanimivo je, da so eksplicitne definicije samega pojma, torej postjugoslovanskega filma, v teh razpravah dokaj redke. Implicitno pa lahko iz korpusov filmov, ki jih posamezni avtorji obravnavajo, sklepamo na ožjo (zgolj filmi, ki se ukvarjajo z razpadom Jugoslavije in $\mathrm{z}$ njegovimi posledicami $\mathrm{v}$ družbah držav naslednic) in širšo zamejitev (vsi filmi, nastali po letu 1991 na ozemlju nekdanje SFRJ). Sam sem v prepričanju, da mora predpona post odražati jasno zvezo s tistim, čemur je pridodana, bolj naklonjen ožji različici; razširil bi jo le še na obravnavo mednacionalnih odnosov v Jugoslaviji, ki so vplivali na dogajanje ob razpadu države (kot denimo državljanska vojna med jugoslovanskimi narodi in političnimi grupacijami med drugo svetovno vojno).

Balkanski in postjugoslovanski film sta se v filmskih študijah zadnjih dveh desetletij izkazala za močan ideološki aparat, za orodje prenašanja političnih sporočil, ki služijo določeni oblasti ali ideologiji. Na to razpravo se bom navezal tako, da bom predstavil doslej teoretsko najizčrpneje obdelan postjugoslovanski film, Podzemlje (1995) Emirja Kusturice, režiserja, rojenega in odraščajočega v sekularni muslimanski družini v Sarajevu, ki pa se je v času razpadanja SFRJ opredelil za srbsko identiteto, pri kateri vztraja vse do danes. Bistveno manj pa sta bila v filmskih študijah obravnavana naslednja Kusturičeva postjugoslovanska filma, Življenje je čudež (2004) in Na mlečni poti (2016), ki ju bom kot reprezentativna primerka srbske kinematografije obravnaval zato, ker je Kusturica še vedno prvo avtorsko ime vseh kinematografij z območja nekdanje Jugoslavije. Predstavil pa bom tudi teoretsko recepcijo ideoloških razsežnosti hrvaške poosamosvojitvene kinematografije; tudi tu bom dodal lastno analizo nekaterih novejših, filmskoteoretsko še nereflektiranih hrvaških filmov in televizijskih nadaljevank. Potem ko so filmske študije v zadnjem desetletju zaznavale »normalizacijo« 
oziroma »konsolidacijo« postjugoslovanskega filma, se pravi, povratek filmske umetnosti te regije k umetniški avtonomiji (Pavičić, 2011), ter celo obrise nove kozmopolitske perspektive postjugoslovanskega filma (Murtić, 2015), se predvsem po novem valu hrvaške ideološke produkcije zadnjih let velja vprašati, ali nismo priča neke vrste regresiji v filmske ideološke diskurze iz 90. let 20. stoletja, in če smo, ali ti diskurzi ostajajo povsem enaki kot tedaj ali pa so z leti vendarle kako mutirali. V zvezi z novejšim opusom Emirja Kusturice se lahko vprašamo, kako vplivna ostaja njegova balkanistična interpretacija jugoslovanskih vojn $\mathrm{v}$ globalnem kontekstu avtorskega filma danes. Prav tako pa ne smemo zanemariti tistih tokov v novejšem srbskem in hrvaškem filmu, ki ideološko zaznamovanim filmom neposredno nasprotujejo - moja teza bo, da so novejši srbski in hrvaški ideološki filmi in serije pravzaprav svojevrstna obrambna "preventiva« ali »kurativa« zoper umetniška sporočila srbskih in hrvaških avtonomnih filmov, slednji pa predstavljajo odkrito konfrontacijo z ideologijo prvih. ${ }^{1}$

\section{Teoretsko ozadje}

Pri pojmovanju ideologije izhajam iz Žižkove, na Sloterdijku temelječe konceptualizacije: pri ideologiji gre za masko, ki ne prikriva preprosto realnega stanja stvari, temveč ideološko popačenje že zavzema cinično distanco do družbene realnosti. Cinični subjekt se zaveda, da je ideološka maska prevara, a vendar pri njej vztraja, »najdeva razloge za to, da masko ohrani« (Žižek, 2011, 32). Ideologija je nekakšen korelat sanj, sanjam podoben konstrukt, ki mu ne moremo ubežati z odpiranjem oči in s poskusom uvideti realnost, kakršna je v resnici - edini način, da ideološkim »sanjam « ubežimo, je v soočenju s trdim jedrom realnosti, ki se v teh »sanjah « naznanja (op. cit., 53). Psihoanalitične implikacije teh tez daleč presegajo namen pričujočega članka; iz njihovih bistvenih poudarkov pa bom prišel do naslednjih ugotovitev: nekateri filmski in televizijski avtorji s področja razpadajoče in razpadle Jugoslavije so v svoja dela zavestno vpletali ideološka sporočila, katerih namen je bil zakrinkati družbeno realnost, za to pa so imeli vsaj dva notranjepolitična razloga - izogibanje priznanju lastne sokrivde (na primer vojnih zločinov lastne strani) in nasprotovanje glasovom znotraj lastne strani, ki bi se bili s trdim jedrom realnosti pripravljeni soočiti -, verjetno pa tudi zunanjepolitična razloga razpihovanja žerjavice in ugajanja zahodnjaškim stereotipom o

1 Za kakšno drugo priložnost pa naj ostane obravnava ideoloških razsežnosti preostalih postjugoslovanskih kinematografij, predvsem bošnjaške, pa tudi slovenske, ki je nanizala osupljivo malo filmov o osamosvojitveni vojni. Morda zgolj tri: kratki igrani film Vse je pod kontrolo (1992) Metoda Pevca, celovečerec Felix (1996) Boža Šprajca in televizijski celovečerec 1991: Neizstreljeni naboj (2011) Jureta Pervanja; bežno se spopadov v Sloveniji dotakne še srbsko-slovenska koprodukcija Sivi kamion rdeče barve (2004). Iz tako skromne bere se porodi vprašanje, ali se ideološka drža slovenskih filmskih avtorjev in še zlasti programskih odločevalcev bolj kot v posnetih kaže v neposnetih filmih. Prav tako bi veljalo razmisliti tudi o ideoloških sporočilih tistih "postjugoslovanskih filmov«, ki so jih proizvedle države izven regije - najodmevnejši primer te podkategorije je bržčas $V$ deželi krvi in medu (2011), z bošnjaškega stališča posneti prvenec ameriške režiserke Angeline Jolie. 
Balkanu. Avdiovizualni mediji, kot sta film in televizija, seveda sodijo med najvplivnejše prenašalce sporočil sodobnega časa, zato lahko upravičeno predpostavljamo, da imajo sporočila teh filmov in nadaljevank nemajhen družbeni domet; analiza njihove širše recepcije $\mathrm{v}$ javnosti bi zahtevala posebno razpravo. $\mathrm{V}$ pričujočem članku se bom omejil na diskurzivno analizo političnih sporočil iz izbranih primerov novejših srbskih in hrvaških filmov in serij.

Za kakšno ideologijo v postjugoslovanskem filmu sploh gre? Filmske študije zadnjih dveh desetletij so $\mathrm{v}$ filmih iz te regije prepoznale tri medsebojno prepletajoče se ideološke tendence: samoviktimizacijo, samobalkanizacijo in nacionalizem. Tako je Jurica Pavičić v monografiji Postjugoslavenski film: stil i ideologija (2011) postavil tezo o treh večjih slogovnih gibanjih v postjugoslovanskem filmu. Film samoviktimizacije je prevladoval na Hrvaškem v Tuđmanovem obdobju, vključeval pa je črno-belo prikazovanje Hrvatov med domovinsko vojno (in celo ustašev med drugo svetovno vojno) kot žrtev, Srbov (in med drugo svetovno vojno komunistov) pa kot njihovih rabljev. Estetske značilnosti te paradigme, ki služijo temeljnemu občutenju lastnega naroda kot brezmadežne žrtve, so izrazit propagandizem, črno-bela karakterizacija, poudarjena prepričevalnost in skoraj didaktična pojasnjevalnost (nadvse pristranskega) diskurza, raba sovražnega govora, demonizacija etničnega drugega ter melodramatična dramaturgija. Najznačilnejša primera sta Bogorodica (1999) Nevena Hitreca in Četverored (1999) Jakova Sedlarja. Hkrati je soobstajal film samobalkanizacije, ki je balkanska vojna žarišča ali Balkan nasploh prikazoval kot območje nepopravljivega kaosa, v katerem so občasne vojne nekaj »naravnega«, poudarjajoč hrabrega balkanskega borca kot tukajšnjo avtohtono človeško vrsto. $\mathrm{V}$ to paradigmo po Pavičiću sodijo vse največje uspešnice postjugoslovanskega filma 90. let 20. stoletja, torej Pred dežjem, Lepe vasi lepo gorijo, Rane, Sod smodnika, pa tudi Podzemlje. Pavičićev film samobalkanizacije ni nič drugega kot v filmska izrazna sredstva prevedena tendenca balkanizma, kot jo je leta 1997 razkrinkala bolgarska zgodovinarka Maria Todorova v znani monografiji Imaginarij Balkana: šlo je torej za ponotranjenje zahodnjaških stereotipov o Balkanu kot nepoboljšljivem leglu kaosa. Za estetiko samobalkanizacijskega filma so po Pavičiću značilne groteska, hiperbola in parodija ter logika burleske, nemega in animiranega filma. Bistvo samobalkanizacije je za Pavičića v tistem, kar so strukturalisti prepoznali kot »naturalizacijo kulture«, se pravi, v predstavljanju nečesa zgodovinskega in kulturno pogojenega kot docela naravnega. Tretji Pavičićev slogovni trend pa je film normalizacije oziroma konsolidacije, v katerem po letu 2000 grotesko zamenja minimalistični realizem, balkanske vojščake izpodrinejo protagonisti z realnimi življenjskimi problemi, sposobni spremembe in katarze, pasivno dramaturgijo žrtev iz filmov samoviktimizacije pa nadomesti aktivno razreševanje problemov in travm, »delo na sebi« (Pavičić, 2011, 21-22). Drugi avtorji, v prvi vrsti Dina Iordanova (2001), Pavle Levi (2011) in Dino Murtić (2015), so v filmih, ki jih je Pavičić označil 
kot samoviktimizacijske ali samobalkanizacijske, dali velik poudarek tudi nacionalističnim sestavinam. Oglejmo si, kako so se vse tri ideološke tendence, samoviktimizacija, samobalkanizacija in nacionalizem, sprepletle v Kusturičevem Podzemlju.

\section{Balkanistični nacionalizem Emirja Kusturice}

O tem, da Emir Kusturica v neformalnih posvečenih krogih filmske umetnosti še dandanašnji ostaja prvo avtorsko ime z območja nekdanje SFR Jugoslavije, dovolj zgovorno priča dejstvo, da je bil kot edini filmski ustvarjalec s tega območja povabljen v osrednje tekmovalne sporede festivalov v Cannesu, Benetkah in Berlinu s prav vsemi svojimi igranimi celovečerci - torej z vsemi devetimi, od leta 1981 do leta 2016. Vrhunec kariere je doživel leta 1995, ko je bil celo nekakšna filmska »osebnost leta - za Podzemlje je v Cannesu prejel že svojo drugo zlato palmo, ${ }^{2}$ film pa je postal predmet žgočih debat. ${ }^{3}$ Kusturica je Zahodu spretno ponudil prav tisto kost, ki je Zahodu, obotavljajočemu se intervenirati v vojni, izvabljala sline: sporočilo o vojni in sovraštvu kot naravnem stanju Balkana (Murtić, 2015, 47). ${ }^{4}$

Podzemlje, epska filmska alegorija zgodovine druge Jugoslavije od njenega spočetja v komunističnem odporu zoper nemške okupatorje do njenega nasilnega razpada $\mathrm{v}$ 90. letih 20. stoletja, v eno združuje magični realizem, koreografijo ekscesnega uživanja in teater absurda. Filmsko dogajanje se začne aprila 1941, ko Nemci zbombardirajo in okupirajo Beograd, medtem ko prebivalstvo Maribora in Zagreba nemške okupatorje pozdravlja. Glavna junaka sta člana beograjskega komunističnega odpora, Marko in Črni, ki sta hkrati ljubezenska rivala v razmerju do gledališke igralke Natalije. V določenem trenutku Marko Črnega ter še nekaj svojih prijateljev in sorodnikov skrije v veliko klet, zaklonišče, kjer proizvajajo orožje za partizansko gibanje. A ko se vojna konča, Marko prebivalcem kleti tega ne pove. Z Natalijo ostane na površju in v novi državi postane pomemben pripadnik nomenklature, "podzemljanom " pa še naprej predvaja nacistične zvoke in alarme za nevarnost zračnih napadov; orožje, ki mu ga v kleti proizvedejo, prodaja na črnem trgu. Leta 1961 se klet vdre in njeni prebivalci spoznajo resničnost, Marko in Natalija pa pobegneta iz države. Ponovno ju srečamo leta 1992, že ostarela, ko na bojišču enega od spopadov med nasilnim razpadanjem Jugoslavije znova prekupčujeta $\mathrm{z}$ orožjem in postavljata oderuške cene. Ker poveljnik paravojaške enote, ki sta ji skušala prodati orožje, zaukaže, da je treba vojne dobičkarje pokončati po hitrem postopku, ju nemudoma ustrelijo, polijejo z bencinom in zažgejo. Omenjeni poveljnik pa je nihče drug kot sam Črni, ki to, da je dal ubiti prav svojo davno ljubezen in svojega nekdanjega prijatelja, izve šele potem, ko je že prepozno,

2 Prvo je prejel leta 1985 za Očeta na službenem potovanju, film o posledicah Titovega spora z Informbirojem.

3 Obširno o njih poroča Iordanova (2001, 111-135).

4 O tem, kako se je Zahod obotavljal intervenirati v jugoslovanskih vojnah, gl. Malcolm (2011, 399-451). 
da bi ju še lahko rešil; obupano skuša pogasiti njuni trupli, a seveda zaman. Kusturica pripoved kljub vsemu zaokroži karnevalsko, s fantazijskim prizorom svatbe, na kateri se zberejo vsi živi in mrtvi junaki filma, vsi v svojih najboljših letih; edini moralno neoporečni protagonist filma, Markov duševno bolni brat Ivan, zdaj popolnoma zdrav, pa neposredno v kamero spregovori o bolečini, žalosti, a tudi veselju, s katerimi se bodo spominjali nekdanje Jugoslavije. Sledi zaključni napis: »Ta zgodba nima konca.»

Da gre pri Podzemlju v prvi vrsti za balkanizem, se pravi za tisto, čemur bo $\mathrm{Pa}$ vičić pozneje rekel samobalkanizacija, je že leta 1997 poudaril Slavoj Žižek. V spisu z jamesonovskim naslovom »Multiculturalism, or the Cultural Logic of Multinational Capitalism $«^{5}$ je ugotovil, da politični pomen tega filma ni prvenstveno v njegovem nacionalističnem podtekstu (junaški Srbi proti prevarantskim, pronacističnim Hrvatom in Slovencem), temveč v tistem »depolitiziranem « esteticističnem stališču, ki ga je Kusturica leta 1995, ob slavju na cannskem festivalu, zavzel v intervjuju za Cahiers $d u$ cinéma: da je Balkan območje, kjer je vojna »naravni pojav«, območje nedojemljivega, mitskega cikla polnokrvnih strasti, ki predstavlja nasprotje dekadentnemu in anemičnemu zahodnemu življenju. Za Žižka je to učbeniški primer balkanizma, ki deluje na podoben način kot Saidov koncept orientalizma - Balkan torej postane brezčasen prostor, na katerega Zahod projicira svoje domišljijske predstave in ga dojema v skladu z njimi (Žižek, 2014, 184).

Kljub temu pa filmske študije v zadnjih 15 letih povečini izpostavljajo prav nacionalistični podtekst Podzemlja. Pavle Levi je v monografiji Disintegration in Frames osvetlil pomen uporabe nemške pesmi Lili Marleen, ki je bila uglasbljena leta 1938 in po nemški okupaciji Srbije redno predvajana na Radiu Beograd. Ta pesem namreč v Podzemlju spremlja dve ključni montažni sekvenci: 1) navdušen sprejem Nemcev v Mariboru in Zagrebu ter hkratno razdejanje Beograda aprila 1941 ter 2) pot Titovih posmrtnih ostankov od Ljubljane do beograjske Hiše cvetja leta 1980. Konotacije teh dveh sekvenc so po Leviju naslednje: prva utrjuje diskurz o »srbskem položaju žrtve " nacistov in njihovih kolaborantov ustašev, diskurz, ki je leta 1986 dobil celo akademski blagoslov v obliki zloglasnega Memoranduma Srbske akademije znanosti in umetnosti (SANU), ${ }^{6}$ pri drugi sekvenci pa pesem z nacistično resonanco spremlja pogreb največje ikone jugoslovanskega socializma, kar ustvarja asociativni vtis o »smrti diktatorja « in - ker je ista pesem spremljala že sekvenco arhivskih posnetkov iz leta 1941 - tega diktatorja, ki je bil pol Hrvat, pol Slovenec, hkrati umešča v "protisrbsko koalicijo«, ki jo vodijo Hrvati in Slovenci (Levi, 2011, 82-83). Kusturica torej uporabi posnetke mariborskega in zagrebškega salutiranja Nemcem, ne uporabi pa posnetkov, ki bi prikazovali srbsko uničevanje Vukovarja ali Sarajeva, ali posnetkov, »kako so

5 Ta je prvič izšel jeseni 1997 v 225. številki New Left Review (str. 28-51). Tu ga navajam po izdaji v kompilaciji Žižek (2014).

6 V tem je jasno razberljiva tudi samoviktimizacijska prvina Podzemlja. 
se v Beogradu zmagoslavno poslavljali od jugoslovanske vojske in njenih tankov, ki so odhajali v vojno na Hrvaško in v Bosno proti skorajda neoboroženemu ljudstvu « (Cerović, v Levi, 2011, 83). Te Kusturičeve odločitve, skupaj z odločitvijo, da so nezanesljivi partijski tovariši Marka in Črnega jasno označeni kot Musliman, Hrvat in Srb, se v končni instanci zvedejo na paradoksalno hkratno zagovarjanje jugoslovanstva kot nadetničnega ideala in etnopartikularističnih interesov srbskega naroda, kar pa ni nikakršen Kusturičev novum, saj je bila podobno shizofrena že SANU, ko je pozivala $\mathrm{k}$ nujnosti obstanka federativne Jugoslavije in obenem zagovarjala srbski nacionalni interes (op. cit., 84). S kancem cinizma (ali morda le zgodovinskega realizma?) bi lahko rekli, da je sinteza te teze (poudarjanja jugoslovanstva) in antiteze (poudarjanja srbskega nacionalnega interesa) v razumevanju Jugoslavije kot Velike Srbije ali »Srboslavije« - torej kot takšne Jugoslavije, v kateri bi imela glavno ali celo edino besedo Srbija. Takšna pa je bila Kraljevina Jugoslavija, ki danes najbrž predstavlja ideal zgolj srbskim rojalistom, kar soscenarist Podzemlja Dušan Kovačević je, občasno pa se tako opredeljuje tudi Kusturica.?

Če se je Podzemlje jugoslovanskim vojnam posvetilo le v svojem zadnjem in najkrajšem delu, pa sta naslednja Kusturičeva (ožje) postjugoslovanska filma skoraj v celoti posvečena vojni v Bosni in Hercegovini ter za nazaj učinkujeta komplementarno: Življenje je čudež vojno leta 1992 »otvori«, Na mlečni poti pa jo leta 1995 zaključi.

Življenje je čudež (2004) se torej začne leta 1992 v srbskih hribovskih vaseh vzhodne Bosne, blizu meje s Srbijo. Ko v republiki izbruhne bošnjaško-srbski spopad, železničarskemu inženirju Luki vpokličejo sina Miloša, nadarjenega nogometaša, v srbsko vojsko, a že kmalu postane ujetnik muslimanske strani. Luka pa dobi v varstvo bošnjaško ujetnico, medicinsko sestro Sabaho, ki jo namerava srbska stran izmenjati za Miloša (»oni nam Miloša, mi njim dekle, pa mirna Bosna« je replika, ki lepo povzame kusturičevsko poenostavljanje kompleksnih zgodovinskih dogajanj). A med Luko, ki mu je bila žena pobegnila z nekim Madžarom, in Sabaho se vname ljubezen, kar ogrozi načrtovano izmenjavo ujetnikov. Goran Gocić ta sinopsis povzame z besedami, da gre za melodramo, v kateri »vojna ljudi zbližuje, mir pa jih razdvaja« (Gocić, 2005, 62). Ta strnjeni povzetek izjemno dobro zgošča cinično plat Kusturičevega postjugoslovanskega opusa: storiti vse, da se ne očrni srbska stran in da se ne izpostavi srbska krivda, primerjati vojno z naravno katastrofo, izpostaviti pozitivne učinke vojne, kar koli, da le ne bi kritično ovrednotil srbske politike in družbe ter srbske vloge v vojnah na Hrvaškem, v BiH in na Kosovu. Vsi trije njegovi ožje postjugoslovanski filmi so posneti s srbskega zornega kota, in če bi jih gledal kdo, ki o (post)jugoslovanski zgodovini ni poučen, bi dobil vtis, kakor da so jugoslovanske vojne nekaj, kar so utrpeli predvsem (ali celo samo) Srbi. Življenje je čudež tako preigrava razvpiti umor bosanskega Srba na

7 Danes tako Kovačevića kot Kusturico najdemo v kronskem svetu srbske kraljeve družine Karađorđević: https://royalfamily.org/krunski-savet/?lang=lat, dostop 19. 1. 2020. 
poroki 1. marca 1992 (incident, ki je bil neke vrste predigra v vojno v BiH), prikazuje bežanje srbskih civilistov pred muslimanskimi enotami po hribih vzhodne Bosne in vključuje prizor, v katerem Sabaho med begom proti Srbiji ustrelita muslimanska paravojaka, ki jo označita kot »četnikušo«. Na drugi strani so srbski zločini nad Bošnjaki omenjeni le skozi replike in še to komaj zaznavno.

Na mlečni poti (2016) prikazuje sklepno fazo vojne leta 1995 v srbskem delu Hercegovine. Protagonist Kosta (igra ga sam Kusturica) je vaški raznašalec mleka, ki je, odkar je moral gledati, kako so njegovemu očetu z motorno žago oddrobili glavo, razvil čudaške navade: na oslu jezdi med frontnimi črtami in se pred soncem, a tudi pred granatami, ščiti z navadnim dežnikom, za talisman pa ima sokola, ki mu sedi na rami. Zaljubi se v Nevesto, hčer Srba in Italijanke, ki je v srbski del Hercegovine pribežala iz srbske paradržave Krajine na Hrvaškem (prav mogoče, da zavoljo hrvaške operacije Nevihta, ki je avgusta 1995 povzročila eksodus Srbov iz Krajine - kar ponovno poudarja vtis, da se vojna in z njo povezani migracijski tokovi pri Kusturici dogajajo samo Srbom). Toda Nevesto bo kmalu dohitela preteklost v podobi njenega bivšega partnerja, angleškega generala, proti kateremu je pričala na sodišču: potem ko bo vojna $\mathrm{v}$ Hercegovini že končana, bodo na prizorišče - pod pretvezo humanitarne pomoči in nadzora območja premirja - stopili angleški komandosi, iščoč Nevesto in neusmiljeno uničujoč vse, kar jim stopi na pot do tega cilja. Nevesta bo v spektakularnem akcijskem finalu na minskem polju zletela $\mathrm{v}$ zrak, užaloščeni Kosta pa se bo pomenišil, prijateljeval z medvedi in naslednjih petnajst let s kamenjem prekrival minsko polje, kjer se je končalo Nevestino življenje. Že sam opis vsebine pove, da je Kusturica do realizacije tega filma, za katerega je scenarij napisal sam, že povsem izgubil stik z resničnostjo. Film naj bi bil posnet, kot pove uvodni napis, "po treh resničnih zgodbah in mnogih fantazijah« - toda povedan je kot absurdna nadrealistična pravljica, katere potek si izmišljuje, kot je zapisal Varietyjev kritik Jay Weissberg, šestletni otrok (Weissberg, spletni vir, 2016). Konec filma je sicer bolj tragičen in elegičen kot običajno, lahko ga označimo kot prvi zares tragičen konec kakega Kusturičevega filma po Domu za obešanje (1988), vendar pa je tisto, kar ostane v spominu, predvsem Kusturičev prikaz angleških "humanitarcev«, ki pridejo v srbski del Hercegovine na osebno maščevalno misijo zločinskega angleškega generala in pobijajo vaščane kakor v računalniški igri. Sporočilo te drzne hiperbole je, da je Zahod v Bosni in Hercegovini posredoval le toliko, kolikor je bilo v njegovem lastnem interesu, in da je bilo njegovo posredovanje zločin nad srbskim prebivalstvom BiH. Nobenega dvoma torej ni, da Kusturica v 21. stoletju še naprej forsira oba svoja vodilna motiva iz Podzemlja, Balkan kot potresno območje in Srbe kot večne žrtve. Še naprej instrumentalizira filmski medij v politične in ideološke namene, le da je v zadnjih 15 letih estetsko opešal na raven avtopilota. Funkcija zamegljevanja resničnosti v Kusturičevih postjugoslovanskih filmih pa je v zamolku vloge srbskega nacionalizma $\mathrm{v}$ (post)jugoslovanskih mednacionalnih konfliktih. 


\section{4 Življenjepis in operacija, čista kot solza}

Hrvaška kinematografija in televizijska produkcija sta od Tuđmanove dobe, ko sta ju prevevala samoviktimizacija in izrazit hrvaški nacionalizem (Pavičić, 2011, 108-124), v naslednjih dveh desetletjih navdušujoče napredovali in zvrstili hvalevreden niz nedogmatičnih produkcij, avtonomnih filmskih in televizijskih stvaritev, v katerih sta postavili pod vprašaj dominantno ideologijo hrvaške politike o brezmadežnosti domovinske vojne. Najboljša primera sta Brešanove Priče (2003), ki jih je navdihnil hrvaški paravojaški poboj srbske družine Zec v Zagrebu 7. decembra 1991, in Jurić-Devićevi Črnci (2009), ki tematizirajo hrvaška mučenja in uboje srbskih civilistov v zapuščeni garaži v Osijeku leta 1991. Ta sijajna filma sta se lotila natanko tistega soočenja s trdim jedrom realnosti, z lastno soodgovornostjo za zločine, ki se mu ideološko konotirani srbski in hrvaški filmi izogibajo. ${ }^{8}$

Toda v zadnjem desetletju je v hrvaški filmski in televizijski produkciji spet mogoče zaznati povratek $\mathrm{k}$ nacionalističnemu in antikomunističnemu diskurzu zadnjega desetletja 20. stoletja. HRT-jeva igrano-dokumentarna nadaljevanka Jugoslovanske tajne službe avtorjev Miljenka Manjkasa in Miroslava Rezića se je - s sodelovanjem zgodovinarjev - leta 2012 popolnoma osredotočila na jugoslovansko obveščevalno preganjanje in likvidiranje hrvaških emigrantov v tujini. Kot že leta 1999 film Četverored je tudi ta nadaljevanka minimizirala krvavo zgodovino ustaštva, maksimizirala pa protihrvaško delovanje jugoslovanskih komunistov. Leta 2017 je kot poganjek Jugoslovanskih tajnih služb nastala še igrana nadaljevanka Varuh dvorca, v kateri je Lukas Nola podal avtorsko vizijo dogajanja v 80. letih 20. stoletja: glavni lik je hrvaški komunistični obveščevalec, ki počasi zapira obroč okrog hrvaškega emigranta v Nemčiji, a nazadnje so likvidirani vsi, ki so v akciji kakor koli sodelovali, tudi glavni lik, kajti sledi za zločinom je treba zabrisati. Nolova nadaljevanka je premestila poudarek s hrvaške samoviktimizacije na nihilizem komunizma, v katerem nihče ni več varen pred zločinsko državo, niti tisti, ki zvesto delajo zanjo. Kristijan Milić pa je leta 2014 posnel Številko 55, igrani celovečerec o srbski obkolitvi in likvidaciji dvajsetih hrvaških vojakov v vasici Kusonje pri Pakracu 8. septembra 1991. Tukaj je bila na delu evolucija paradigme samoviktimizacije: čeprav so kusonjski »četniki« brez zadržkov demonizirani, pa Hrvatje niso pasivne, usodo sprejemajoče žrtve, temveč odločni borci, ki vztrajajo v boju, dokler je še kaj upanja. Podoben pogled na domovinsko vojno je Milić posredoval še v igrani nadaljevanki Pogrešani (2020), v kateri

8 Enako - odkrito soočenje s trdim jedrom realnosti - velja tudi za srbski Tovor (2018) Ognjena Glavonića, ki prikazuje brezinteresno sodelovanje običajnega srbskega državljana pri prevažanju trupel pobitih kosovskih Albancev leta 1999, ter za nekatere srbske in hrvaške dokumentarce v zadnjih letih (Glavonićeva Globina dva je dokumentarni predhodnik Tovora, hrvaški dokumentarec Srbenka pa govori o medvrstniškem nasilju v hrvaških šolah, zlasti nad otroki srbske narodnosti). Pomemben je tudi prispevek hrvaškega režiserja Daliborja Matanića k personalizaciji domovinske vojne v Zenitu (2015), filmu, ki se sicer ne sooča z lastnimi demoni, vendar suvereno zagovarja kozmopolitski humanizem, o katerem v svoji monografiji piše Murtić (2015). Preseganje ideološkosti v Matanićevem opusu sem analiziral v Čakalić (2019). 
si hrvaška vojaška enota, ki obtiči na ozemlju srbske paradržave Krajine, utira pot nazaj na varno skozi nepredvidljiv in nevaren teren, kjer zločine izvajajo samo »četniki«.

Ključni hrvaški filmsko-televizijski projekt o domovinski vojni pa je v zadnjem desetletju bržkone Vrdoljakov biografski spektakel o generalu Anteju Gotovini, General (2019). Življenjska zgodba neizšolanega mladeniča, ki je iz komunistične Hrvaške odšel v francosko tujsko legijo, se leta 1991 vrnil osvobajat domovino, poleti 1995 pa že kot general odigral ključno vlogo v operaciji Nevihta, ki je Hrvaški povrnila ozemlje srbske paradržave Krajine, zamolči kriminalna poglavja njegove biografije in beg pred haaškim sodiščem; po uspehu Nevihte in generalovi poroki s polkovnico Dunjo Zloić sledijo le še zelo kratki dokumentarni posnetki s prvega in drugega haaškega sojenja Gotovini (na prvem leta 2011 je bil spoznan za krivega vojnih zločinov in obsojen na 24 let zapora, na drugem leta 2012 pa je bil s tesno večino oproščen). Podobam oprostilne sodbe, ki naj razblinijo še najmanjši dvom o legitimnosti ključne hrvaške vojaške operacije v obdobju jugoslovanskih vojn, utrdijo teren prizori Gotovine, kako pred in med Nevihto nenehno svari pred nesorazmerno uporabo sile; da je v operativnem smislu storil premalo, da bi zločine nad srbskimi civilisti preprečil, General ne omenja. ${ }^{9}$ Biografija, skratka, čista kot solza. Še bolj pomembno pa je, da je v filmu tudi sama operacija Nevihta brezmadežna (kar je uradno stališče hrvaške politike po letu 1995, ne glede na to, kdo je na oblasti). Uničevanje in ropanje srbskih hiš je pripisano lokalnim pridaničem in individualni volji maščevalno razpoloženih vojakov, o strateško spodbujenem izgonu srbskega naroda in pobojih srbskih civilistov (Goldstein, 2008, 312) pa se ne govori. Vrdoljak se sicer izogne demonizaciji Srbov (opazen delež srbskih likov v Generalu nima slabih namenov) in ne zapade v izrazito samoviktimizacijo; objokujejo se predvsem vojaške, v nobenem pogledu pasivne žrtve domovinske vojne, medtem ko se trpljenje hrvaških civilistov ne izpostavlja preveč. Lahko bi rekli, da je General programski filmski tekst malce bolj liberalnih, proevropskih krogov znotraj hrvaške konservativne politične opcije, ki pa seveda še vedno ne odstopajo od dominantnega ideološkega diskurza oziroma konstitutivnega mita sodobne hrvaške državnosti o brezhibnem sijaju Nevihte. Ko se je film v razširjeni obliki pojavil na televiziji, so hrvaška družbena omrežja podivjala od negativnih odzivov na njegovo »diletantsko« produkcijo, polno montažnih in vsebinskih napak, na neskončne štabne dialoge, na telenovelistično igro ter na patetično in klišejsko glasbeno spremljavo. Pri tem pa ni šlo samo za morebitno znašanje levičarsko usmerjenih spletnih provokatorjev nad produkcijo, ki niti na formalni ravni ni upravičila finančnega vložka najmanj 15 milijonov kun, temveč so se odklonilni odzivi pojavili celo s strani veteranov domovinske vojne. Negativno sta se namreč do sicer naklonjenega, a po njunem mnenju nerealističnega (preveč statičnega, dialoškega in naivnega) prikaza hrvaških poveljnikov opredelila tudi generala Ante Roso in Davor Domazet - Lošo (Pavičić, spletni vir, 2020).

9 O tem in o Gotovinovem kriminalnem ozadju ter begu pred Haagom več v Đikić, I. in drugi (2014). 
Recepcijo Generala v hrvaški javnosti bo zanimivo spremljati tudi v prihodnje, in šele čas bo pokazal, kakšna bosta prava politična teža in vpliv tega filmsko-televizijskega epa.

\section{Sklep}

V komunistični Jugoslaviji je dominantna filmska ideologija precej črno-belo slavila junaška dejanja partizanov in demonizirala nemške okupatorje med drugo svetovno vojno, toda v ozadju je cvetel tudi družbenokritični, estetsko vplivni, v tujini prepoznani in nagrajevani »črni val«, ki je pridobitve komunistične revolucije postavljal pod vprašaj. Po vojnem in neposrednem povojnem obdobju 90. let 20. stoletja, ko so v Srbiji in na Hrvaškem prevladovali nacionalno oziroma ideološko "pravoverni« filmi, so se srbski in hrvaški filmarji v prvih desetletjih 21. stoletja občutno razbremenili potreb ali zahtev po instrumentalizaciji filma v propagandne namene. »Poraz diskurza, ki je v nekdanji Jugoslaviji idoliziral oborožene može, je skoraj popoln, saj noben pomemben film ali filmar z Balkana ne slavi več mitske figure vojščaka« (Murtić, 2015, 7). Toda ideološkost filmov iz regije ni nikoli povsem poniknila, v zadnjih letih pa se celo znova krepi. Drži sicer, da se je tudi Kusturica v 21. stoletju odpovedal mačizmu svojega Podzemlja, zato pa se Vrdoljakov General toliko intenzivneje spogleduje z mitsko karakterizacijo svojega osrednjega lika. In tudi sicer je v hrvaški kinematografiji in televizijski produkciji zadnjih let mogoče zaznati močan porast utrjevanja hrvaške politične samopodobe neoporečnih pozitivcev, ki ga lahko razložimo z željo, da bi se izognili neprijetnim vprašanjem o temnih plateh lastne zgodovine (nasilja). Z odmikanjem nasilnega razpada nekdanje skupne domovine v vse bolj oddaljeno preteklost je mogoče opaziti le, da se v teh novih hrvaških ideoloških produkcijah, pa še to ne v vseh, mehča demonizacija Srbov. V ideoloških produkcijah razbiram tudi poskus nevtralizirati filme, ki so si drznili pogledati pod ideološko prevleko in so pod njo odkrili zločine lastne strani. $Z$ vidika filmarja, ki se nameni posneti ideološki film, namreč svojega stališča ni treba zoperstaviti le političnim nasprotnikom v tujini ali domovini, temveč je treba preglasiti tudi umetniške prispevke njegovih stanovskih kolegov, ki njegovo ideološko stališče spodkopavajo.

Emir Kusturica je v tem pogledu pomemben zato, ker ga avtorska filmska javnost, katere utrip merijo zlasti festivali v Cannesu, Benetkah in Berlinu, še vedno obravnava kot z naskokom prvo avtorsko ime iz regije. Res je sicer, da njegov zasebni živalski vrt palm, levov in medvedov - torej festivalskih nagrad - v tem stoletju ni dobil naraščaja. Kljub temu pa ostaja grenak priokus, da je Kusturičeva prežvečena in preživeta ideološka konstrukcija (ki brez očitnega sporočilnega razvoja, v estetskem pogledu pa celo $\mathrm{z}$ naraščajočo izpetostjo, že več kot dvajset let v sebi združuje srbski nacionalizem, samoviktimizacijo in samobalkanizacijo) v svetu avtorskega filma še vedno toplo sprejeta, ne da bi bila vsaj enakovredna - če že ne večja - pozornost namenjena avtonomnim 
umetniškim stvaritvam postjugoslovanskih kinematografij. Glavonićev Tovor se je moral sprijazniti s spremljevalno cannsko sekcijo Quinzaine des Réalisateurs, Jurić-Devićevi Črnci, eden nespornih vrhuncev postjugoslovanskega filma in bržkone najboljši sodobni dedič jugoslovanskega »črnega vala«, pa se sploh niso prebili na nobenega od največjih filmskih festivalov. Zdi se, da se mednarodna filmska javnost ob kompleksnih fasetah jugoslovanskih vojn in njihovih posledic ne znajde najbolje, podobno kot se ni najbolje znašla splošna mednarodna javnost, ko so jugoslovanske vojne potekale.

\section{Bibliografija}

Čakalić, A., Kozmopolitski humanizem v filmih hrvaškega režiserja Daliborja Matanića, Časopis za kritiko znanosti 277,2019 , str. 203-225.

Đikić, I. in drugi, Gotovina: stvarnost in mit, Ljubljana 2014.

Gocić, G., Emir Kusturica - Kult margine, Beograd 2005.

Goldstein, I., Hrvaška zgodovina, Ljubljana 2008.

Iordanova, D., Cinema of Flames: Balkan Film, Culture and the Media, London 2001.

Jameson, F., Thoughts on Balkan Cinema, v: Subtitles: On the Foreignness of Film (ur. Egoyan, A., Balfour, I.), Cambridge, Massachusetts 2004, str. 231-255.

Levi, P., Razpad Jugoslavije na filmu, Ljubljana 2011.

Malcolm, N., Bosna: Kratka povijest, Sarajevo 2011.

Murtić, D., Post-Yugoslav Cinema: Towards a Cosmopolitan Imagining, London, New York 2015.

Pavičić, J., Postjugoslavenski film: stil i ideologija, Zagreb 2011.

Todorova, M., Imaginarij Balkana, Ljubljana 2001.

Žižek, S., Poskusiti znova - spodleteti bolje, Ljubljana 2011, str. 9-59.

Žižek, S., The Universal Exception, London, New York 2014, str. 171-204.

\section{Spletni viri}

Kraljevska porodica Srbije, Krunski savet, https://royalfamily.org/krunski-savet/?lang=lat, dostop 19. 1. 2020.

Pavičić, J., Jurica Pavičić o Generalu, https://www.jutarnji.hr/magazin/jurica-pavicic-o-generalusada-ne-postoji-popularnija-stvar-nego-sto-je-bacanje-blatom-na-vrdoljakov-uradak-a-nitko-ne-postavlja-pravo-pitanje/9864838/, objavljeno 18. 1. 2020, dostop 21. 1. 2020.

Weissberg, J., Film Review: On the Milky Road, https://variety.com/2016/film/reviews/on-themilky-road-venice-film-review-1201856571/, objavljeno 9. 9. 2016, dostop 19. 1. 2020.

\section{Filmografija}

1991: Neizstreljeni naboj (2011, Jure Pervanje)

Bogorodica (Bogorodica, 1999, Neven Hitrec)

Četverored (Četverored, 1999, Jakov Sedlar)

Črnci (Crnci, 2009, Zvonimir Jurić in Goran Dević)

Dom za obešanje (Dom za vešanje, 1988, Emir Kusturica) 
Felix (1996, Božo Šprajc)

General (General, 2019, Antun Vrdoljak)

Globina dva (Dubina dva, 2016, Ognjen Glavonić)

Jugoslovanske tajne službe (Jugoslavenske tajne službe, 2012, Miljenko Manjkas idr.)

Lepe vasi lepo gorijo (Lepa sela lepo gore, 1996, Srđan Dragojević)

Na mlečni poti (Na mlečnom putu, 2016, Emir Kusturica)

Oče na službenem potovanju (Otac na službenom putu, 1985, Emir Kusturica)

Podzemlje (Podzemlje, 1995, Emir Kusturica)

Pogrešani (Nestali, 2020, Kristijan Milić)

Pred dežjem (Pred doždot, 1994, Milčo Mančevski)

Priče (Svjedoci, 2003, Vinko Brešan)

Rane (Rane, 1998, Srđan Dragojević)

Sivi kamion rdeče barve (Sivi kamion crvene boje, 2004, Srđan Koljević)

Sod smodnika (Bure baruta, 1998, Goran Paskaljević)

Srbenka (Srbenka, 2018, Nebojša Slijepčević)

Številka 55 (Broj 55, 2014, Kristijan Milić)

Tovor (Teret, 2018, Ognjen Glavonić)

$V$ deželi krvi in medu (In the Land of Blood and Honey, 2011, Angelina Jolie)

Varuh dvorca (Čuvar dvorca, 2017, Lukas Nola)

Vse je pod kontrolo (1992, Metod Pevec)

Zenit (Zvizdan, 2015, Dalibor Matanić)

Življenje je čudež (Život je čudo, 2004, Emir Kusturica)

\section{Aleš Čakalić}

\section{Ideologija v novejšem srbskem in hrvaškem filmu}

Ključne besede: srbski film, hrvaški film, postjugoslovanski film, ideologija, balkanizem, nacionalizem, samoviktimizacija

V srbski in hrvaški filmski produkciji 90. let 20. stoletja so prevladovala ideološka sporočila, od ponotranjenih zahodnjaških balkanističnih stereotipov do izrazito nacionalističnih konotacij, ponekod pa je bila na delu tudi poudarjena samoviktimizacija. A če so filmske študije v zadnjem desetletju že izrazile previden optimizem, da se je postjugoslovanski film v 21. stoletju normaliziral oziroma konsolidiral, ali celo, da se v njem rišejo obrisi nove kozmopolitske perspektive, želim sam opozoriti na to, da je instrumentalni, ideološka sporočila prenašajoči srbski in hrvaški film tudi po letu 2000 še vedno dejaven. $V$ ta namen analiziram diskurze $v$ postjugoslovanskem opusu srbskega režiserja Emirja Kusturice ter v nekaterih izbranih primerih novejše hrvaške filmske in televizijske produkcije. Nekatera izmed teh del tudi še globoko v naš čas perpetuirajo ideološke diskurze o superiornosti ali vsaj brezmadežnosti lastnega naroda, vzpostavljene z razraščanjem nacionalizma med razpadanjem SFR Jugoslavije, in jih prilagajajo sodobnim okoliščinam. Tem vzorcem ideološkega filma pa nasprotujejo igrani in dokumentarni filmi iz regije, ki odstrejo ideološko prevleko in pod njo odkrijejo zamolčana poglavja lastne zgodovine. 


\section{Aleš Čakalić}

\section{Ideology in recent Serbian and Croatian cinema}

Keywords: Serbian cinema, Croatian cinema, post-Yugoslav cinema, ideology, Balkanism, nationalism, self-victimization

The Serbian and Croatian film production of the 1990s was dominated by ideological messages, ranging from internalized Western stereotypes of the Balkans (the so-called 'Balkanisms') to outright nationalistic connotations, and in some cases, self-victimization has also been noted. Yet if film studies have reported a cautious optimism during the past decade, announcing a sort of normalization or consolidation of the post-Yugoslav cinema in the $21^{\text {st }}$ century, or even that a new cosmopolitan perspective is taking shape within it, I would like to draw attention to the fact that instrumental Serbian and Croatian cinema, which transmits ideological messages, remained active after 2000. To support my thesis, I analyse the discourses in the post-Yugoslav body of work of the Serbian filmmaker Emir Kusturica, and in selected examples of recent Croatian film and TV production. The films in question are found to be perpetuating chauvinist discourses, set up by the growth of nationalism during the disintegration of Yugoslavia, adjusting them to contemporary circumstances. These samples of ideological cinema, however, are opposed by certain regional feature and documentary films that remove the ideological veil and discover underneath some concealed chapters of the nations' histories.

\section{O avtorju}

Aleš Čakalić je študiral filozofijo in zgodovino na Filozofski fakulteti Univerze v Ljubljani. Bil je kustos v Pokrajinskem muzeju Maribor, več let je objavljal filmsko publicistiko, sodeloval pa je tudi z založniškim oddelkom Slovenske kinoteke. V okviru doktorskega študija humanističnih znanosti na Fakulteti za humanistični študij (ISH) univerze Alma Mater Europaea raziskuje interdisciplinarni preplet filmskih študij, estetike, politike in balkanologije v postjugoslovanskem filmu.

\section{About the author}

Aleš Čakalić studied philosophy and history at the Faculty of Arts, University of Ljubljana. He has worked as a curator at Pokrajinski muzej Maribor (Regional Museum Maribor), published in the field of film journalism for several years, and collaborated with the publishing department of Slovenska kinoteka (Slovenian Cinematheque). As part of his doctoral studies in the field of humanities at the University of Alma Mater Europaea, he is researching the interdisciplinary intertwining of film studies, aesthetics, politics and Balkanology in post-Yugoslav cinema. 